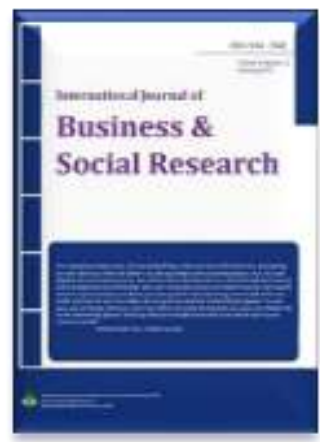

\title{
Linkages among E-Service Quality, Satisfaction, and Usage of E-Services within Higher Educational Environments
}

\author{
Henry Ataburo', Abdul Samed Muntaka², Emmanuel Kwaku Quansah³
}

\begin{abstract}
To date, literature on e-service quality (E-SQ) has mainly been on conceptualisation and measurement issues within the e-retail environments. Empirical research on E-SQ and its consequences in 'pure' service context has not been forthcoming. In expanding knowledge in light of this, this study examined a modified E-SQ scale within a university's e-services setting. In addition, the linkages existing among E-SQ (in this 'pure' service environment) and satisfaction and e-service usage frequency was estimated using SEM in LISREL 8.5 by relying on questionnaire data collected from three hundred and eighteen students of Kwame Nkrumah University of Science and Technology (Ghana). Results obtained provide support for a modified 7-dimension E-SQ scale employed. Further, the results indicated that E-SQ only has a significant positive indirect effect on usage frequency through satisfaction. The implication of these results is that firms that provide higher quality of e-services are more likely to satisfy their customers, which would in turn influence their commitment to purchase and re-purchase intent. In the case of the current study, the implication is that, universities with quality e-services would have students finding their e-services to be satisfactory and consequently be consistent in the use of e-services to improve learning and administrative communication. E-services quality therefore has both financial implication for universities in terms of cutting administrative costs, and a ripple effect of students' perception of quality on the image and competitiveness of the university.
\end{abstract}

Keywords: E-service quality, higher academic institutional environment, satisfaction, usage frequency. JEL Codes: C25, G2, O19.

Available Online: 18-04-2017.

DOI: http://dx.doi.org/10.18533/ijbsr.v7i3.1040

This is an open access article under Creative Commons Attribution 4.0 License, 2017.

\section{INTRODUCTION}

\footnotetext{
${ }^{1}$ Kwame Nkrumah University of Science and Technology, Information Systems and Decision Science Kumasi, Ashanti Region, GH. E-mail: ataburohenry@gmial.com

2 Kwame Nkrumah University of Science and Technology, Information Systems and Decision Sciences, School of Business Kumasi, Ashanti, GH. E-mail: abusamgh@yahoo.com/asmuntaka.ksb@knust.edu.gh, Phone: +233(0)205515494

3 Kwame Nkrumah University of Science and Technology, Information Systems and Decision Sciences, School of Business Kumasi, Ashanti, GH., E-mail: equansah.ksb@knust.edu.gh
} 
As a means of market extension, the web and internet technology now serve as a strategic tool for businesses to extend their services and product offerings across the world at a relatively cheaper cost (Swaid \& Wigand, 2009). As a result, e-services over the years are intensifying, and changing the dimensions of competition for both domestic and foreign businesses ( $\mathrm{Li}$, Liu, \& Suomi, 2009) through emphasis on superior quality services and convenience (Sohn \& Tadisina, 2008). Unlike the past where online presence was the prerogative of retail businesses, e-service is being adopted increasingly by purely service institutions and governments to enhance the quality of their services (Kim-Soon et al., 2014) rather than the mere online presence for informative purpose; which has given room for complexity in the conceptualisation of e-services today.

The rationale for this study can be found in the statement of Kilburn and Kilburn (2003) that, universities, apart from imparting knowledge are also businesses. Meaning that they cannot continue to ignore growing trends in their customer's (student's) demand for e-services and remain competitive. Meanwhile, Cronin et al. (1992) indicate that one of the most powerful issues influencing strategy in business today is service quality. They argue that service quality has been found to positively influence customer satisfaction. E-service quality cannot therefore be isolated in this regard. According to KimSoon et al. (2014), universities have been at the forefront of online activity mostly for informative and admission purposes to the general public. However, recent trends show that universities are now going beyond simple online presence to using the internet platform to channel their services to best meet the needs of both distant and on-campus students as well as staff (Kim-Soon et al., 2014; Sutarso \& Auharmdi, 2011). Apart from using e-services to cut down on administrative costs by way of letting students perform some self-services online (such as course registration, lecturer assessment, etc.), universities through e-services are now breaking geographical boundaries and hence intensifying competition among domestic and foreign educational institutions. It is hence not surprising that advertisement of online degree courses today keeps popping ubiquitously on almost every webpage.

The issues that, however, remain to be answered include; how much attention educational institutions of higher learning should pay to the quality of the e-services they provide; and whether or not institutions of higher learning in developing countries stand to benefit from paying more attention to increasing the quality of the e-services they provide to their students. These questions notwithstanding, the main objective of this study was to find out the influence e-service quality has on the level of usage and satisfaction students derive from the e-services and whether universities in Ghana stand to benefit from paying more attention to increasing the quality of the e-services they provide.

The concept of e-service quality has been defined to include provision of superior customer experience in the pre-transaction, transaction, and post-transaction cues in an e-commerce environment (Zeithaml et al., 2002; and Santos, 2003). While the concept of quality and its measurement in services, with respect to the SERVQUAL instrument, has been variously studied in depth, its main limitation as debated, is on its seeming lack of physical presence in the e-services setting (Shapor et al., 2011; Cristobal et al., 2007; and Swaid \& Wigand, 2009). As a result, the subject matter has lately gained considerable attention in both academia and industry.

While literature on e-service is burgeoning, its conceptualisation and measurement has mostly been limited to e-retail firms, with very few studies focusing on purely service institutions. Insights from existing literature reveal that the focus of e-service quality studies have mostly been on designing and refining scales, while most applied studies have concentrated on web design in e-retail settings (Cristobal et al., 2007; Li \& Suomi, 2009). Therefore, Parasuraman et al. (2005) after developing and validating the E-Service quality (E-SQ) scale for evaluating e-retail services suggested that future studies adopt and modify the scale for purely service websites to validate the scale in purely service websites. Moreover, current literature portrays that perceived E-SQ and satisfaction are strong predictors of customer loyalty in e-services. However, in an institutional setting such as a university, the customer (student) would have paid for the service already, and may have no other choice but to keep using the service, or may do so to satisfy an institutional requirement, which is quite different from what a customer would normally experience on an e-retail site. The identified issues and these gaps, in addition 
to the scanty literature of e-service especially in the pure-service or institutional settings in developing countries have hence propelled this study.

To enable us carry out this study in the real life context of the student and obtain in-depth evidence (Saunders et al., 2007), the case study approach was adopted. Data was collected using mainly questionnaires from a sample of three hundred and sixty undergraduate students from the six colleges of the Kwame Nkrumah University of Science and Technology (KNUST). Questionnaires for the study were developed from the measures for E-SQ adapted from the E-Serqual and E-recovery dimensions of Parasuraman et al.(2005). The respondents were selected using the stratified, quota and convenient sampling techniques. With the response rate of $88.33 \%$, the valid data was subjected to analysis using SEM in Lisrel 8.5. The study found that e-service quality had a significant positive impact on satisfaction and also satisfaction had significant positive influence on usage frequency. These results are consistent with the findings of Wolfinbearger and Gilly (2003); Ozkan and Koseler (2009); Al-Mushasha and Nassuora (2012); Ramayah et al. (2012) and Sanayei and Jokar (2013). This study also found that eservice quality had an insignificant direct effect on usage frequency. The effect of e-service quality on usage frequency was mediated by satisfaction. This finding is also consistent with the findings of Cristobal et al. (2007) that e-service quality could not predict website loyalty significantly except through satisfaction. The economic implication of these findings is that for institutions of higher learning especially in Ghana to fully achieve the benefit of providing e-services (such as reduction in administrative and other operations cost), they must get their students to increase their patronage of the e-services provided. This can however only be achieved if the students are satisfied with the eservices provided which can only be achieved by enhancing the quality of the e-services.

The rest of this paper is presented in four sections. Section 2 presents the literature review and discusses such topics has the concept of e-services, e-service quality and why it is important, conceptualization of e-service quality, web-design, and the efficiency of e-service in the educational context. The Technology Acceptance Model (TAM), Theory of Reasoned Action (TRA), and Theory of Planned Behaviour (TPB) were also reviewed. Three hypotheses were presented in this study and these were also presented in this section. Section 3 discusses the methodology adopted for the study. The Confirmatory and Exploratory Factor Analysis carried out, the reliability and validity tests as well as the results from structural equation model are also presented in this section. The final section presents the discussions and conclusions arrived at by the study. Also presented in this final section are the policy implications.

\section{LITERATURE REVIEW}

\section{$2.1 \quad$ THE CONCEPT OF E-SERVICES}

Literature on e-services in the $21^{\text {st }}$ Century is fast growing due to the advancement of computer technology today, and the turbulent nature of the business environment. The concept of the worldwide web and business transactions have evolved over the decades and still, show prospects for further exploitation. Chaffey (2009) distinguishes between the two common internet business models; e-business and e-commerce. The author defined e-commerce as conducting buying and selling activities via the web (purely transactional), and goes on to define e-business to encompass all interactions and relationship management of an organisation's business partners, and managing some business processes online (which is more than just transaction). According to Zeithaml et al. (2002), inefficiency in e-commerce such as; customers' inability to complete online transactions, poor information contents and accessibility issues on some websites, wrong deliveries among others have become common among e-commerce businesses and these constitute the reasons giving rise to increasing attention on e-service quality. Therefore, it is essential for businesses to shift their attention from simple web presence which emphasizes solely providing information, to focusing attention on the quality of 'eservices' if they are to compete favourably (Zeithaml et al., 2002; and Swaid \& Wigand, 2009). 
Zeithaml et al. (2002) defined 'e-service' to encompass all pre-transaction, transaction and posttransaction 'cues' of an e-commerce or B2C transaction. Following that, Santos (2003) also defined eservice as the provision of superior experience with respect to the interactive flow of information other than just the role of service in an internet space. It must be however emphasised that the use of service in this context is not limited to purely service firms (such as transportation services, banking services, insurance services, etc.) but also to all the ancillary services (all other resultant time-perishable intangible benefits) that may accompany retailing of even tangible products online (Fitzsimmons \& Fitzsimmons, 2006).

\subsection{E-SERVICE QUALITY AND WHY IT IS IMPORTANT}

E-service quality (E-SQ) has been defined as “... the extent to which a website facilitates efficient and effective shopping, purchasing, and delivery of products and services" to the customer (Parasuraman 2005). Also, Santos (2003) after reviewing the definitions of E-SQ by several other authors, defines eservice quality as "the consumers' overall evaluation and judgment of the excellence and quality of eservice offerings in the virtual marketplace". Chaffey (2009) adds that service quality delivery through e-commerce is to consider how the site provides customer services at different stages of the buying process. Thus, e-service quality is not only dependent on just the purchase activity, but also on all other ancillary services that may precede, accompany, or follow after the actual purchase. Fassnacht \& Koese (2006) and Gummerus et al. (2004) both opine that the definition of e-service quality by Parasuraman et al. (2005) was too narrow; and defined Quality of Electronic Service (QES) with the aim to capture eservice quality in a broader sense, as "the degree to which an electronic service is able to effectively and efficiently fulfil relevant customer needs". In this regard, Wolfinbarger and Gilly (2003) define E-SQ as the perceived quality derived from the beginning to the end of the transaction, including information search, website navigation, ordering, customer service interactions, and delivery and satisfaction with the ordered product. Carefully reviewing all the above, the common theme running through is that customers' perception of an e-service firm's performance (quality) can occur before, during, and after the purchase transaction, which in turn determines their level of satisfaction and consequently their behavioural intents in the future.

E-services however, serve as a two-edged sword in competition. In as much as the internet platform makes competition keen, it also presents tools that makes it easy to manage customers, win their loyalty and induce repurchase/revisit. The turbulent nature of online marketing therefore suggests the need for online businesses to build a supplementary strategic capacity to respond to these environmental opportunities and threats (Wang, 2003; Chaffey, 2009). With e-services becoming the new dimension for competition among B2C/e-commerce firms, there is the need for firms to focus their attention on delivering superior quality services over the web regardless of the type of business, and product or service offered (Swaid \& Wigand, 2009; and Wang, 2003). Among the reasons customers leave a company, over $68 \%$ of them leave because of 'poor service experience'and for other less significant factors such as price (10\%) and product issues (17\%) (Feinberg et al., 2000 cited in Chaffey, 2009). In congruence, e-service is increasingly becoming a critical determinant for attracting and retaining customers; hence the need for firms' attention on e-service and the quality thereof (Li \& Suomi, 2009).

\subsection{CONCEPTUALISATION OF E-SERVICE QUALITY}

In conceptualizing E-SQ, Zeithaml et al. (2002) developed an E-SQ gap model similar to the gap model they had earlier developed for offline service quality. In the E-SQ gap model, these authors explain that, the customer's perception of E-SQ is predicted by the service fulfillment gap which is contributed by other three gaps resulting from the company's activities. The 'Information Gap' which can be likened to the market research gap in the SERVQUAL 5 quality gap model, explains the discrepancy between management's beliefs about the customer requirements against the customer's actual web requirements. Georgiadis (2009) in comparing the perceptions of providers and customers concluded 
that while providers' perceptions are in agreement with customers' perceptions with regards to the dimensions of e-service quality, their items under each dimension were different between the two groups.This discrepancy goes a long way to contributing to the second gap (design gap) which happens as a result of the design and operationalization of the website which does not match management's belief about customer requirements. A third gap (communication gap) emanates from the inconsistency in how the company markets the website in relation to the actual design and operation of the website. The discrepancy between the customer's website requirements and what s/he experiences after using a website is termed the 'fulfillment gap' which is contributed by the other three company induced gaps.

Although the definition of the two constructs (SERVQUAL and E-SQ) are similar on some dimensions, eservices possess unique characteristics based on the channel of delivery, service content and product type (Collier \& Bienstock, 2006; Li \& Suomi, 2009; Swaid \& Wigand, 2009; Zeithaml et al., 2002). For instance,some authors posit that the mere absence of physical persons, the technology-based medium of delivery, and the self-service elements in e-services suggest the need for dimensions such as trust, ease of use, website content and functionality at the expense of competence, courtesy, cleanliness, friendliness, etc.(Cox \& Dale, 2001; Li \& Suomi, 2009).The original developers of the SERQUAL model also in this new trend of E-SQ have made a tremendous contribution by developing a scale for its measurement. Together with the contribution of several other researchers from the field of service, quality, e-business and management information system, etc., their works have provided a pool of knowledge giving insights for further studies in the field and also serving as an invaluable guide to the industry. In the review of extant literature on e-services, several dimensions of E-SQ were discovered. Most of these dimensions cut across most studies; although interpreted differently. Table 1 summarises a few contributors to the development of E-SQ measurement from literature and the key dimensions running through existing literature.

Table 1: Key contributions in understanding the concept of e-service quality

\begin{tabular}{|c|c|c|}
\hline Author & Conceptualisation & Dimensions \\
\hline $\begin{array}{l}\text { Swaid\& } \\
\text { Wigand } \\
\text { (2009) }\end{array}$ & $\begin{array}{l}\text { Explored e-retailing Service Quality dimensions } \\
\text { on various loyalty forms (preference loyalty, } \\
\text { price tolerance, and complaining behaviour) }\end{array}$ & $\begin{array}{l}\text { Website usability, Information } \\
\text { quality, Reliability, Responsiveness, } \\
\text { Assurance and Personalization }\end{array}$ \\
\hline $\begin{array}{l}\text { Cristobal et al. } \\
(2007)\end{array}$ & $\begin{array}{l}\text { PeSQ (Perceived Service Quality) a predictor of } \\
\text { customer satisfaction and loyalty for both buyers } \\
\text { and information searchers }\end{array}$ & $\begin{array}{l}\text { Web design, Customer service, } \\
\text { Assurance, and Order management }\end{array}$ \\
\hline $\begin{array}{l}\text { Parasuraman, } \\
\text { Zeithaml, \& } \\
\text { Malhotra } \\
\text { (2005) }\end{array}$ & $\begin{array}{l}\text { E-ServQual Scale: Developed a more retail } \\
\text { oriented scale that incorporated electronic } \\
\text { service recovery dimensions }\end{array}$ & $\begin{array}{l}\text { Efficiency, fulfillment, } \begin{array}{r}\text { system } \\
\text { availability, }\end{array} \\
\text { responsiveness, compensation, } \\
\text { contact. }\end{array}$ \\
\hline $\begin{array}{l}\text { Wolfinbarger } \\
\text { \& Gilly (2003) }\end{array}$ & $\begin{array}{l}\text { The eTailQ dimensions developed by the authors } \\
\text { were used to predict overall quality comparing } \\
\text { across varied e-service users (browsers, goal- } \\
\text { oriented, frequent buyers, books/music, auction, } \\
\text { etail, etc.) }\end{array}$ & $\begin{array}{l}\text { Fulfillment/reliability, Website } \\
\text { design, Customer service, and } \\
\text { Security/privacy }\end{array}$ \\
\hline $\begin{array}{l}\text { Loiacono et al } \\
(2002)\end{array}$ & $\begin{array}{l}\text { Developed } 12 \text { WebQual dimensions and used } \\
\text { them to predict customers' intention to } \\
\text { purchase and revisit, using product (CD's and } \\
\text { Books) and service (airline and hotel } \\
\text { reservations) websites. }\end{array}$ & $\begin{array}{l}\text { Informational fit-to-task, Tailored } \\
\text { Communications, Trust, Response } \\
\text { Time, Ease of Understanding, } \\
\text { Intuitive Operations, Visual Appeal, } \\
\text { Innovativeness, Emotional Appeal, } \\
\text { Consistent Image, On-Line } \\
\text { Completeness, and Relative } \\
\text { Advantage. }\end{array}$ \\
\hline $\begin{array}{l}\text { Yoo \& Donthu } \\
(2001)\end{array}$ & $\begin{array}{l}\text { Conceived e-service 'internet shopping' as } \\
\text { 'SiteQual', a place where one could browse, }\end{array}$ & $\begin{array}{l}\text { Ease of Use, Aesthetic Design, } \\
\text { Processing Speed, and Security }\end{array}$ \\
\hline
\end{tabular}


evaluate, order and purchase products and services. Scale was evaluated on Gap, BestBuy, eBay, Amazon, Buy, and Walmart, using students.

\subsubsection{WEBSITE DESIGN}

It is identified that since e-service is in a virtual environment, the tangible elements would constitute website design and its visible features (Li \& Suomi, 2009; Kim-Soon et al., 2014). These authors argue that for a website to attract customers, its design should be "appealing and well organized"; have a "consistent and standardized navigation"; "well-organized appearance of user interface"; offer Quick downloading; and ensure "Easy use of the online transaction". Similarly, Collier \& Bienstock (2006) found in their study on measuring the service quality in e-retailing that, the design of a website, is a crucial element in customers' evaluation process in placing an order on a website. Both Fassnacht \& Koese (2006); and Loiacono et al. (2002) referred to the term differently as 'graphic quality' and 'visual appeal' respectively, and also found it to be one of the criteria customers employ in evaluating an eservice.

While Parasuraman et al. (2005) did not acknowledge website design on the basis that online shoppers are more goal oriented (which may be true in a typical e-retail setting), the dimension could be a vital factor to customers of purely service institutions, e-governmental sites, educational sites, etc. (Wolfinbarger \& Gilly 2003; Kausar \& Bokhari 2010; and Cox \& Dale 2001).

\subsubsection{EFFICIENCY}

Parasuraman et al. (2005) identified efficiency as one of the core e-service quality dimensions defined as "the ease and speed of accessing and using..." a website. In this definition is embedded three key elements; ease of use/usability/convenience, speed of use/access, and accessibility. Kim-Soon et al. (2014) and Sohn \& Tadisina (2008) identified that the overall ease or convenience in using a website contributed to the evaluation of website quality and reuse. Fassnacht \& Koese (2006) also identified 'ease of use' as one of the elements in delivering quality apart from attractiveness, information and technical quality. In their study of customers' evaluation of self-service technologies in public transport, Reinders et al. (2007) found that, two dimensions (reliability, and ease of use), were the most important attributes. Li et al. (2009) likewise found in an empirical study on online travel services that (trust and ease of use) were the most critical and important facets of customers' evaluation of e-service quality.

\subsubsection{FULFILMENT}

Both Parasuraman et al. (2005) and Li \& Suomi (2009) identified 'Fulfilment' as a key element in customers' evaluation of e-service quality. Fulfillment describes the extent to which the site's promises about order delivery and item availability are fulfilled. In a similar thought, Li \& Suomi (2009) posit that right information about products or services availability is important when buying, and has a strong influence on future purchase intentions and customers' confidence in the company. Also, fulfillment, referred as 'Order Management' by Cristobal et al. (2007), have other attributes such smooth running of the system for transaction processing, accurate promises about delivery and availability to modify and or defer transaction without commitment.

\subsubsection{SYSTEM AVAILABILITY}

A service is only useful when it is available at the time it is needed and where it is needed. Parasuraman et al. (2005) describes the dimension as the technical functionality of a website. Thus as part of customers' quality evaluation process, they look out for the correct functioning of the website, with respect to how it is supposed to respond users input, as they log onto the site. This suggests correct functioning of servers and links; available and responding to requests all the time. The authors 
conceived the dimension in terms of its availability for business, the website running right away when launched, does not crash and or freeze during use.

\subsubsection{PRIVACY/SECURITY}

Contrary to offline shopping where mostly only the physical appearance of the customer is known, eservice transactions mostly require more details of the customer (name, residential address, credit card details, etc.) in order to complete a transaction. Friedman et al. (2000) cited in Zeithaml et al. (2002) define 'privacy' as comprising protecting customers' personal information, not sharing customers' personal information without their informed consent. They also defined 'security'as protecting users from fraud (identity theft and misrepresentation) especially from the use of their financial information on the website (Collier \& Bienstock, 2006). Parasuraman et al. (2005) also defines security/privacy as the extent to which the customer believes the safety of the site from intrusion and exposure of personal information. Security has been referred to as one high-risk factor and a key barrier to online purchasing; and defines it as the "freedom from danger, risks or doubts during the service process" (Li \& Suomi 2009; and Cox \& Dale 2001). Adding to that, it has been said that security risk perceptions have a strong impact on attitude toward use of online financial services (Montoya-Weiss et al., 2000).

\subsubsection{RESPONSIVENESS}

In the opinion of Li \& Suomi (2009) this dimension is more likely to be relevant when customers have questions or problems and contacts the e-service provider. They referred responsiveness in the eservice setting to the promptness of the e-service provider to customers through digital media when customers have questions or problems, which make customers more comfortable during purchasing and continue purchasing without interruption. Attributes of the responsiveness dimensions include adequate contact information, prompt responses to customers' requests, timely responses to customers, adequate response time, and quickly solve problems (Li \& Suomi, 2009). Parasuraman et al. (2005) explains responsiveness as the effective handling of problems and returns through the website. It was viewed by the authors as one of the e-service recovery dimensions which is only relevant when customers encounter problems on the website and contacts the e-service provider. Swaid (2008) adds by revealing attributes such as making available contact addresses in all advertising channels, accurate and appropriate email responses, and showing sincere interest and actually dealing with customers' problems, as the manifestation of e-service responsiveness.

\subsubsection{COMPENSATION}

Compensation is the second recovery e-service quality dimension proposed by (Parasuraman et al., 2005). They explained it as the degree to which site compensates customers for service failures online, or other forms of problems they encounter. Technology sometimes do fail, and the customer online would normally expect some compensation from the service provider. These may take the form of undelivered order, or delivery of wrong orders, etc. and how the website responds to such disappointments would determine the trust that customers would have in the e-services. According to the authors, compensation may take the form of the website accepting return of wrong goods delivery, refunding customers' monies for an unfulfilled service, etc.

\subsubsection{CONTACT}

Parasuraman et al.(2005) again stressed on the availability of assistance through telephone or online representatives for the particular e-service. When customers encounter problems with the website, there should be someone they should be able to contact or complain/report their challenge too. When such mediums are available, customers have the confidence of initiating a transaction knowing that they can rely on such a contact in case they encounter any problem. More especially if there is a live person they can always contact other than an answering machine or a robot.This position was confirmed in the study of (Ozkan \& Koseler, 2009) who in the educational setting found that assistants 
attitude, and personalised attention provided by e-service administrative staff were positively associated with students' satisfaction.

\subsection{E-SERVICE IN THE EDUCATIONAL CONTEXT}

Given the relevance of E-SQ, studies examining E-SQ in the educational setting is growing in numbers. Kim-Soon et al. (2014) opined that the development of electronic-based services to students emerged to satisfy the need to optimize (become more efficient and effective) through automating the process of delivering learning and administrative services. This means sharing university work load with students by way of instituting self-services. Universities as institutions, or purely service firms, unlike retail firms, suggest that the conceptualisation of e-service quality in these setting may deviate a little from a retail setting. While a couple of studies have attempted to develop measurement instruments for educational e-services, this has not been conclusive as they come with varying opinions. For instance, Kausar \& Bokhari (2010) identified usefulness, ease of use, accuracy, web appearance, as the dimensions that related to student satisfaction but Ozkan and Koseler (2009) found that among other factors, 'service quality' [assistants' attitudes (empathy), and the personalised attention provided by the administrative staff] also contributed significantly to students' overall satisfaction with e-services. Again, Al-Mushasha and Nassuora (2012) studied factors determining e-learning service quality in higher education using dimensions such as; interface design, reliability, responsiveness, trust, and personalization.

It is observed that while there is no agreed set of dimensions, the design of website run through most of the works. In the midst of increasing scale development in both e-retail and pure service e-service sites, there is an urgent need to find a common scale whose dimensions can easily be adapted between the two e-service settings, and for comparison purposes (Parasuraman et al., 2005).

\subsection{CONCEPTUAL FRAMEWORK AND HYPOTHESES}

In reviewing processes and criteria customers employ in their assessment of the quality of e-services, several dimensions or conceptualization of e-service quality were identified from several authors and for varying online retail and services outlets which had their root from the Technology Acceptance Model (TAM), Theory of Reasoned Action (TRA), Theory of Planned Behaviour (TPB), and theories on the perceived value/satisfaction and its consequential behavioural attitudes of customers (Davis 1989; and Vankatesh et al. 2003).

Davis (1989) first modeled TAM to explain employees' acceptance of a new information technology based on two variables: the Perceived Usefulness, and Perceived Ease of Use. That is to say, people's behaviour (acceptance and manner of usage) towards a technology is determined by their ability to use the new technology with ease, and how it would help them carry out their tasks more effectively and efficiently. Vankatesh et al. (2003) took the study further by introducing eight theories which combined into a Unified Theory of Acceptance and Use of Technology (UTAUT), which outperformed the eight individual theories by explaining $70 \%$ of the variances in intention to use and usage behaviour of Information Technology.

An opinion is held that, adopting to use e-service which is a kind of self-service from the customer's point of view, is similar to the adoption of new information technology (Parasuraman et al., 2005). Many studies throughout literature have dwelt on these theories to come out with criteria customers' use in assessing E-SQ (as discussed earlier) and the consequential effects on behavioural intents of customers (Zeithaml et al. 2002; Loiacono et al. 2002; Yi \& Hwang 2003; Monsuwé et al. 2004; Parasuraman et al. 2005; Ramayah et al. 2012; Al-adwan \& Smedley 2012; and Rareș 2014). This study therefore draws inferences from these theories to conceptualise the relationship underlining university $\mathrm{E}-\mathrm{SQ}$, student satisfaction, and usage frequency of university e-services. 
Satisfaction is the measure of how well customers' needs are met. Loyalty on the other hand measures the likelihood of a customer to engage in repeat business and other relationships, giving positive word of mouth about a product or service, and making repeat usage of the product or service (Mohsan \& Nawaz, 2011; Parasuraman et al., 2005).Several authors have explored the relationship among e-service quality, satisfaction, and loyalty intention constructs throughout literature. As quality is usually defined from the customers' perspective, dimensions of quality practically would have a direct impact on the needs of the customers and their satisfaction. As customers' needs are met, there is the likelihood that they would be loyal to the service, ceteris paribus. For instance, Sanayei \& Jokar (2013) in their study examined the influence of e-service quality on satisfaction and found the regression route factor $\left(R^{2}\right)$ to be 0.83 . Similarly, Wolfinbarger \& Gilly (2003) studied the relationship between eTailQ factors on overall quality, satisfaction, and loyalty intentions and customers' attitude toward a website, and found that a strong association exist between the constructs with an $\mathrm{R}^{2}$ of 0.63 for eTailQ factors on Satisfaction. Also, in the work of Cristobal et al. (2007), it was established that perceived e-service quality strongly predicts customer satisfaction especially for 'buyers'. In the educational sector, Kausar and Bokhari (2010) also found that quality of University Websites related to student satisfaction.

Given these insights from literature, the study proposes that:

$H_{1}$ : Perceived e-service quality has positive influence on students' satisfaction of university's e-services.

Student loyalty (as may be influenced by the level of satisfaction and perceived e-service quality) in this study has been measured in terms of their frequency of usage of the university's electronic services. A study by Cristobal et al. (2007) on the causal relationships among perceived e-service quality, satisfaction and website loyalty among buyers and information searchers, reported that satisfaction significantly predicts website loyalty.Similarly, Ramayah et al. (2012) sought to examine the relationship between customers' perceived quality and user satisfaction, and the resultant effect of satisfaction on usage continuance of e-learning, using the DeLone and McLean's IS success model in Penang, Malaysia. It was confirmed from their results that perceived quality comprising the dimensions of service quality, information quality, and system quality, positively influence customer satisfaction, and that user satisfaction also has a direct impact on system's continuance usage intention. Kim-Soon et al. (2014) also found that e-services for supporting learning, research and communication positively related to frequency of use of e-services. According to Mohsan and Nawaz (2011), satisfaction is a very crucial scale for loyalty and that even though there could be satisfaction without loyalty, there can hardly be loyalty without satisfaction. They however concluded that for sure, the three constructs; e-service quality, satisfaction, and loyalty are strongly interrelated. In view of these evidences, the study proposes that:

$\mathrm{H}_{2}$ : Perceived e-service quality has a positive influence on frequency of usage of e-services among university students

$\mathrm{H}_{3}$ : Perceive satisfaction has a positive influence on frequency of usage of e-services among university students.

\section{METHODOLOGY}

\subsection{RESEARCH DESIGN AND SAMPLE}

The study's broad context is higher educational institutions in Ghana but the focal institution was the Kwame Nkrumah University of Science and Technology. To test the study's hypotheses, we relied on a case study strategy. A case study strategy was employed as it allows a researcher to study a phenomena in its real life context and also offers the opportunity to obtain in-depth evidence (Kothari, 2004; Saunders et al., 2007). Data was accordingly collected from undergraduate students of Kwame Nkrumah University of Science and Technology (KNUST). Focusing on KNUST was deemed appropriate for addressing the objectives of the study as it is among the top three universities in Ghana 
(Pulse.com.gh, 2015) and also among the first universities in the sub-region to deploy and pioneer webbased applications for teaching, research, learning and communication with external educational stakeholders.

To obtain a representative sample for the study, the stratified and quota sampling techniques (Saunders et al., 2007) were used to select respondents from each of the six colleges of the university (i.e. College of Humanities and Social Sciences, College of Arts and Built Environment, College of Engineering, College of Agricultural and Natural Resources, College of Science, and College of Health Sciences). A quota of sixty (60) students from each college was determined as appropriate, and a convenience sampling technique was used to administer the questionnaires. Questionnaires for the study were developed from insights obtained from a rigorous review existing literature. The measures for E-SQ were adapted from the E-SERQUAL and E-recovery dimensions of Parasuraman et al.(2005). Out of the 360 questionnaires administered, 318 (88.33\% response rate) were retrieved and considered usable for the study. The 318 retrieved responses were fairly even for the six colleges.

\subsection{RELIABILITY AND VALIDITY ASSESSMENT}

The reliability and validity of the scales were assessed using Cronbach alpha (CA) and confirmatory factor analysis (CFA - in LISREL 8.5) respectively. CA values (see Table 2) for E-SQ dimensions, satisfaction, usage frequency, and institutional requirement ranged from .80 to .89 . These are well above the minimum acceptable alpha value of .70 suggested by Pallant (2007). This indicates that there is a high level of internal consistency of the scales and that they are reliable measures of each of their respective constructs. The CFA was conducted using covariance matrix and maximum likelihood estimation methods. To avoid the risk of violating the minimum sample size to parameter scale ratios, a conventional practice was followed (see Boso, Story, \& Cadogan, 2013) to analyse the scale items in subsets before putting all together. The CFA was performed purposely to identify any problematic measures in the constructs that could impair the model test (Boso et al., 2013). The first set of CFA included modified E-SQ dimensions: Website Design, Efficiency, Fulfilment, System availability, Privacy, Responsiveness, Compensation, and Contact. After following a suggested measurement model modification steps (Hair et al., 2014), a satisfactory model was obtained, given: $\chi^{2} / D F[518.37 / 322]=1.61$; RMSEA = .04; NNFI = .95; CFI = .95; SRMR = .05 (Vieira, 2011; Bagozzi \& Yi, 2012; Hair et al., 2014). To demonstrate the higher order construct of E-SQ, a $2^{\text {nd }}$ order CFA model was estimated. The fit indices obtained were acceptable, given: $\chi^{2} / \mathrm{DF}[660.89 / 322]=1.93 ; \mathrm{RMSEA}=.05 ; \mathrm{NNFI}=.93 ; \mathrm{CFI}=.93 ; \mathrm{SRMR}=$ .05; which largely suggests that E-SQas conceived in this study constitutes an underlying structure of its lower order constructs. The loadings ( $t$-values) of the lower order constructs were all positive and significant; given: Design = .60 (8.09); Efficiency = .69 (11.03); Fulfilment = .82 (11.15); System availability $=.63$ (9.60); Privacy = .62 (9.60); Responsiveness = .78 (10.67); Compensation $=.49$ (5.91); Contact $=.43$ (6.69). In the second CFA, a full measurement model was estimated relying on the retained E-SQ measures and including the measures for satisfaction, institutional requirement/bureaucracy, and eservice usage (see Table 2 for items loadings, $t$-values, composite reliability-CR and average variance extracted-AVE). The fit indices for the full measurement model were within acceptable cut-off ranges; given $\chi^{2} / \mathrm{DF}[1100.17 / 647]=1.70 ; \mathrm{RMSEA}=.05 ; \mathrm{NNFI}=.91 ; \mathrm{CFI}=.92 ; \mathrm{SRMR}=.05$. Also, model modification was inspected and there were no correlated errors for the retained items, implying the absence or departure from unidimensionality. The significant positive loadings and satisfactory model fit indices demonstrate convergent validity of the scales. Also, AVEs above .50 and larger than the shared variances between any pair of constructs demonstrate discriminant validity of the scales. The composite reliability of the scales were all above the minimum threshold of .60 (Vieira, 2011; Bagozzi \& Yi, 2012; Hair et al., 2014). There were also several substantive association among the variables [refer to correlation results in Table 3], as many of the coefficients were 0.30 (significant) and above while there were none at .70 and beyond, confirming nomological validity of the proposed model and the absence of multi-collinearity among the predictor constructs respectively (Hair et al., 2014).

\subsection{COMMON METHOD BIAS ASSESSMENT}


Given the self-report nature of the data collection instrument, the issue of common method bias (CMB) became a concern in the study. To assess the extent of CMB in the study, we followed one of the recommended statistical procedures suggested by Podsakoff et al. (2003). We estimated a one-factor model in which all items were specified to load onto a single latent variable. The model fit indices obtained suggest poor model fit to data, given $\chi_{2} / \mathrm{DF}[7523.59 / 1175]=6.40 ; \mathrm{RMSEA}=.13$; NNFI $=.44 ; \mathrm{CFI}$ $=.47$; SRMR $=.10$, which implies that the eleven factor model (see Table 2) fits the data better than a single factor and thus demonstrating the CMB does not sufficiently describe the data used in the study and may not be a major concern (Podsakoff et al., 2003). These results were not surprising as the instrument contained numerous measures which could potentially make it difficult to obtain variances attributable to the method employed rather than to the constructs that the measures represent (Podsakoff et al., 2003).

Table 2: Validity and reliability (full measurement model) results

\begin{tabular}{|c|c|}
\hline \multirow{2}{*}{\multicolumn{2}{|c|}{$\begin{array}{l}\text { Construct/measures } \\
\text { Design }(C A=.80 ; C R=.81 ; A V E=.52)\end{array}$}} \\
\hline & \\
\hline -DSN2: Site is visually appealing and entertaining & $.67^{*}$ (fixed) \\
\hline -DSN3: The site is entertaining & $.67(10.04)$ \\
\hline -DSN4: Choice of colours are appropriate and appealing & $.72(10.63)$ \\
\hline -DSN5: Site's design is innovative & $.80(11.40)$ \\
\hline \multicolumn{2}{|l|}{ Efficiency $(C A=.85 ; C R=.86 ; A V E=.61)$} \\
\hline -EFF1: This site makes it easy to find what I need. & .85 (fixed) \\
\hline -EFF2: It makes it easy to get anywhere on the site. & $.86(17.94)$ \\
\hline -EFF3: It enables me to complete a task/search quickly. & $.73(14.49)$ \\
\hline -EFF4: Information at this site is well organized. & $.67(12.86)$ \\
\hline \multicolumn{2}{|l|}{ Fulfilment $(C A=.86 ; C R=.86 ; A V E=.56)$} \\
\hline -FULL1: Search results are delivered/returned within a suitable time frame. & .69 (fixed) \\
\hline -FULL2: It has in stock the information and web links it claims to have. & $.72(11.71)$ \\
\hline -FULL3: It is truthful about its services and information. & $.83(13.22)$ \\
\hline -FULL4: It makes accurate promises about delivery of information & $.74(11.95)$ \\
\hline -FULL5: It has a complete overview of the University information & $.73(11.86)$ \\
\hline \multicolumn{2}{|l|}{ System availability $(C A=.83 ; C R=.83 ; A V E=.63)$} \\
\hline -SYS1: This site is always available/accessible. & .71 (fixed) \\
\hline -SYS3: This site does not crash. & $.85(13.17)$ \\
\hline $\begin{array}{l}\text {-SYS4: Pages at this site do not freeze after I enter my information or a search } \\
\text { word }\end{array}$ & $.80(12.78)$ \\
\hline \multicolumn{2}{|l|}{$\operatorname{Privacy}(C A=.87 ; C R=.87 ; A V E=.70)$} \\
\hline -PRI1: It protects information about my Web-surfing behaviour. & .80 (fixed) \\
\hline -PRI2: It does not share my personal information with other sites. & $.91(17.21)$ \\
\hline $\begin{array}{l}\text {-PRI3: This site protects information about my student profile, exam results, and } \\
\text { login details. }\end{array}$ & $.79(15.29)$ \\
\hline \multicolumn{2}{|l|}{ Responsiveness $(C A=.84 ; C R=.84 ; A V E=.57)$} \\
\hline -RES1: It takes care of problems promptly & .69 (fixed) \\
\hline -RES2: Frequently asked question are answered & $.76(11.87)$ \\
\hline $\begin{array}{l}\text {-RES4: Email responses are relevant and accurate and appropriate to my } \\
\text { requirements/queries }\end{array}$ & $.81(12.46)$ \\
\hline $\begin{array}{l}\text {-RES5: The website shows sincere interest in resolving any problems I encounter } \\
\text { Compensation }(C A=.80 ; C R=.81 ; A V E=.68)\end{array}$ & $.76(11.82)$ \\
\hline -COM1: This site apologizes for problems/inconveniences it creates. & .76 (fixed) \\
\hline $\begin{array}{l}\text {-COM2: It gives me alternatives when what I search for is not currently available } \\
\text { Contact ( } C A=.89 ; C R=.94 ; A V E=.84)\end{array}$ & $.88(10.37)$ \\
\hline -CON1: This site provides a telephone number to reach the company. & .79 (fixed) \\
\hline -CON2: IT staff and website administrators are accessible anytime I need & $.87(16.92)$ \\
\hline
\end{tabular}


assistance

-CON3: It offers the ability to speak to a live person if there is a problem.

$.90(17.34)$

Satisfaction ( $C A=.87 ; C R=.90 ; A V E=.70)$

-SAT1: I am always happy to visit KNUST's website

.77 (fixed)

-SAT2: I am pleased with the quality of KNUST's online services

$.84(15.34)$

-SAT3: I am satisfied with KNUST's online services

$.81(14.85)$

-SAT4: KNUST's e-services meets my expectations

$.75(13.59)$

Institutional requirement $(C A=.77 ; C R=.87 ; A V E=.69)$

-INS1: In most cases, my visit to the site is to meet the university's requirements

.61 (fixed)

-INS2: I have to use most of the e-services even though I don't benefit from using

$.84(9.58)$

them

-INS3: I have to use most of the e-services even though it is not convenient

$.76(9.64)$

Usage frequency $(C A=.81 ; C R=.82 ; A V E=.53)$

-USE1: I often visit KNUT's website

.71 (fixed)

-USE2: I often use the website in search for information

$.80(11.84)$

-USE4: I usually fall on KNUST's website in learning

$.70(10.74)$

-USE5: I visit KNUST's website at least once every week

$.70(10.79)$

Notes: $C A=$ Cronbach alpha; $C R=$ Composite reliability; $A V E=$ Average variance extracted; ${ }^{*}$ loadings significant at $1 \%$.

Table 3: Inter-construct correlations and descriptive statistics results

\begin{tabular}{|c|c|c|c|c|c|c|c|c|c|c|c|c|}
\hline \multicolumn{2}{|c|}{ Constructs: } & 1 & 2 & 3 & 4 & 5 & 6 & 7 & 8 & 9 & 10 & 11 \\
\hline 1 & Design & & & & & & & & & & & \\
\hline 2 & Efficiency & .490 & & & & & & & & & & \\
\hline 3 & Fulfilment & .407 & .536 & & & & & & & & & \\
\hline 4 & $\begin{array}{l}\text { System } \\
\text { availability }\end{array}$ & $.281^{*}$ & $.312^{*}$ & $.518^{* *}$ & & & & & & & & \\
\hline 5 & Privacy & $.249^{*}$ & .349 & $.448^{* *}$ & .491 & & & & & & & \\
\hline 6 & Responsiveness & $.367^{*}$ & .440 & $.539^{* *}$ & $\begin{array}{r}.421 \\
* *\end{array}$ & .398 & & & & & & \\
\hline 7 & Compensation & $.256^{*}$ & .229 & $.289^{* *}$ & .129 & .327 & .429 & & & & & \\
\hline 8 & Contact & $.227^{*}$ & $\underset{* *}{.291}$ & $.230^{* *}$ & .145 & .186 & $\begin{array}{r}.421 \\
* *\end{array}$ & .357 & & & & \\
\hline 9 & Satisfaction & .498 & .554 & $.523^{* *}$ & $\begin{array}{r}.420 \\
* *\end{array}$ & .339 & .553 & $\begin{array}{r}.231 \\
* *\end{array}$ & .340 & & & \\
\hline 10 & Institutional req. & .080 & .258 & $.198^{* *}$ & .039 & .075 & $\underset{* *}{.218}$ & $.125^{*}$ & .218 & .192 & & \\
\hline 11 & $\begin{array}{l}\text { Usage } \\
\text { frequency }\end{array}$ & .208 & .269 & $.195^{* *}$ & $\underset{* *}{.181}$ & .136 & .268 & .088 & .321 & .335 & .018 & - \\
\hline$M e$ & & 3.15 & 3.30 & 3.27 & 3.40 & 3.60 & 2.91 & 2.95 & 2.70 & 3.07 & 2.79 & 2.61 \\
\hline Sta & ndard deviation & 0.83 & 0.88 & 0.76 & 0.92 & 0.91 & 0.77 & 1.09 & 1.01 & 0.84 & 0.86 & 0.96 \\
\hline
\end{tabular}

${ }^{*} \mathrm{p}<.05 ;{ }^{* *} \mathrm{p}<.01 ; 2$-tailed test.

From Table 3, the mean values for the dimensions of E-SQ indicate that students on the average perceive adequate performance of KNUST's e-services with respect to the first five service quality dimensions (website design, efficiency, fulfillment, and system availability) since each had a mean score above 3.o. However, the responsiveness, compensation, and contact dimensions obtained mean scores lower than the average 3.0). Averaging the mean scores for the eight dimensions returned an overall average of 2.80 , which suggests an unsatisfactory e-service quality. Students were however, on the average, satisfied with e-services of KNUST (Mean $=3.07$ ). The average e-service usage frequency 
among students was below the midpoint 3.0 (Mean $=2.61$ ), and, institutional requirement to use eservice was also below the midpoint (Mean $=2.79$ ). This suggests that, there were no extreme requirements on students to use university's e-services beyond their own reasons.

\subsection{STRUCTURAL MODEL ESTIMATION, RESULTS AND HYPOTHESES EVALUATION}

The study conceptualised a structural model which specified that E-SQ positively affects both students' satisfaction of e-services and usage frequency and that satisfaction positively affects usage frequency. To estimate these relationships, structural equation modelling procedures were followed in LISREL 8.5.

The parameter estimates of the structural model are shown in Figure 1. The fit indices obtained were acceptable; given $\chi^{2} / \mathrm{DF}[1343.38 / 689]=1.95 ; \mathrm{RMSEA}=.06, \mathrm{NNFI}=.89 ; \mathrm{CFI}=.90 ;$ SRMR $=.07$. This suggests that the structural model fits the data well. As depicted in Figure 1 below, the direct path from $\mathrm{E}-\mathrm{SQ}$ to usage frequency was found to be positive but not statistically significant; given $\beta=.19, t=1.53, \mathrm{p}$ $>$.05. These results do not provide enough support for $\mathrm{H}_{2}$, hence it was not accepted. The path from $\mathrm{E}$ SQ to satisfaction was positive and statistically significant $(\beta=.79, t=12.05, p<.001)$; providing support for $\mathrm{H}_{1}$.Also, the path from satisfaction level to usage frequency was found to be positive and significant; given $\beta=.26, t=2.10, p<.05$. These results provide support for $\mathrm{H}_{3}$. Lastly, the control path, that is, the effect of institutional requirement on usage frequency was also found to be statistically insignificant, given $\beta=-.07, t=-.97, p>.05$. The results suggest that $E-S Q$ explains $62 \%$ variations in satisfaction and $E-$ SQ satisfaction and institutional requirement together explains $17 \%$ variations in usage frequency.

Figure 2: Estimated structural model

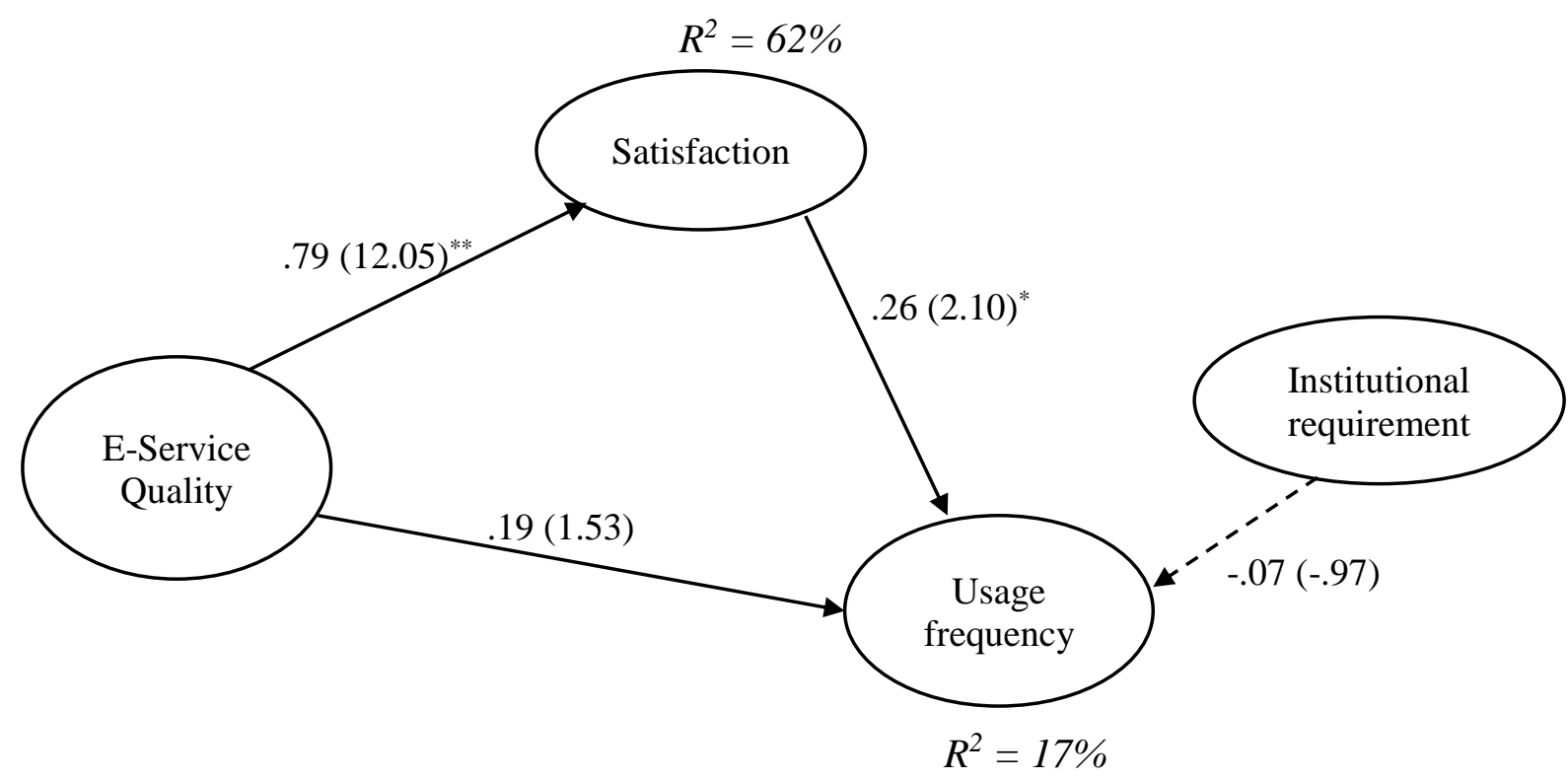

Control path

Notes:

1. standardised coefficients in front of the parenthesis whilst $t$-values are in the parenthesis

2. ${ }^{*} \mathrm{p}<.05 ;{ }^{* *} \mathrm{p}<.01$

3. $\chi 2 / D F[1343.38 / 689]=1.95 ; \mathrm{RMSEA}=.06 ; \mathrm{NNFI}=.89 ; \mathrm{CFI}=.90 ; \mathrm{SRMR}=.07$.

\section{DISCUSSIONS, CONCLUSION AND POLICY IMPLICATIONS}

\subsection{DISCUSSIONS}

The overriding goal of the study was to assess e-service quality (e-SQ) of KNUST and the resultant effect on students' satisfaction and usage frequency as well as the relationship among e-service quality 
and frequency of usage. By employing a much broader conceptualisation of E-SQ, our study's results offer support to the applicability of the instrument in pure service setting, such as an educational environment.

The descriptive results revealed that while overall e-service quality was not satisfactory, students were somewhat satisfied with the e-services provided by the university; however, usage frequency was low. The results obtained also indicated that e-SQ has a significant positive impact on satisfaction and also satisfaction had significant positive influence on usage frequency; thus providing support for hypotheses 1 and 3 of the study. These results are consistent with some previous research findings by authors such as Wolfinbearger and Gilly (2003); Ozkan and Koseler (2009); Al-Mushasha and Nassuora (2012); Ramayah et al. (2012) and Sanayei and Jokar (2013). The insignificant positive effect of e-SQ on usage frequency directly, except interposed by satisfaction in the linkage; suggests the tendency for satisfaction to serve as a conduit for transmitting the positive effect of e-SQ on usage frequency. This finding reinforces existing literature on this subject in both retail and educational settings. For instance, Shapor et al. (2011) and Gummerus et al. (2004) in their study denied the recognition of satisfaction as an antecedent to loyalty in the banking sector; which was extended by Mohsan and Nawaz (2011) that while there could be satisfaction without it resulting into customer loyalty, there could not be loyalty without satisfaction. Other similar studies (see Cristobal et al., 2007; Sanayei \& Jokar, 2013) have reported similar mediating role of satisfaction in the service quality-loyalty linkage. Also, findings of Cristobal et al. (2007) on the causal relationship of e-service quality, satisfaction and web site loyalty for buyers and information searchers revealed among other things that perceived e-service quality could not predict website loyalty significantly (also in Sanayei \& Jokar, 2013); except through satisfaction. This therefore means that the finding of this study with respect to hypotheses 1 to 3 largely affirm findings in existing literature.

Culminating, the study found that the average student's usage of e-services provided by the university was below average because the quality of the e-services was perceived by the students to be low. There is hence an urgent need for the universities to improve the quality of the e-services delivered to students if they want to employ the full benefit of e-services to improve communication and cut administrative cost in the university's operations. They can do this by putting in place policies and the necessary infrastructure that would enhance the quality of the e-services and promote e-service usage among students, taking cognisance of the cost of investing in such infrastructure and the win-win benefit for both the university and the students (Sutarso \& Auharmdi, 2011).

\subsection{CONCLUSION}

This study concludes that quality of e-services has a direct positive and significant effect on the frequency of e-service usage in institutions of higher learning in Ghana. The results suggest that firms that provide higher quality of e-services are more likely to satisfy their customers, which would in turn influence their commitment to purchase and re-purchase intent. With respect to the current study, the conclusion is that, universities with quality e-services would have students finding their e-services to be satisfactory and consequently be consistent in its use to improve learning and administrative communication. This will help the universities reduce cost of communicating manually with their students. On account of this, we further conclude that the Quality of E-services can have both financial implication for universities in terms of cutting administrative costs, and a ripple effect on students' perception of quality on the image and competitiveness of the university. This conclusion is consistent with the conclusions arrived at by Sutarso \& Auharmdi (2011); Kim-Soon et al. (2014); and Kilburn \& Kilburn (2014).

\subsection{POLICY IMPLICATIONS}

The policy implications of the findings of this study are that first; institutions of higher learning must come to terms with the fact that the introduction of e-services into their everyday activities must not 
be to only provide e-services to their students but that as a matter of policy, specific standards of quality must be agreed to with the telecommunication companies providing the bandwidth services to the universities. This is because pursuing high quality of e-service is no longer an option for the managers of higher educational institutions since the nature of demand for education today requires them to be able to offer effective onshore, distant and offshore education in order to compete favourably, given the projected threatening competitive market for university education in Ghana by their foreign counterparts.

Second, the turbulence of competition in today's business environment in general and the institutions of higher learning in particular are worsened daily by the impact of the internet technology. Tertiary institutions in Ghana today are gradually encroaching each other's territory through distance learning on e-platforms. As a result, e-services have become a threshold requirement for these institutions. Since the internet is an open platform, mere presence online is on longer enough. Its drive for success lies in the innovativeness of institutions that are able to deliver a high level of service quality to their students in their online experience.

\subsection{LIMITATIONS AND SUGGESTIONS FOR FUTURE RESEARCH}

The scope of this study was limited to the Kwame Nkrumah University of Science and Technology and even though the students of this university exhibit behaviour that can be likened to the behaviour of students in other universities in Ghana, the generalizability of the findings of this study will have been enhanced if samples were selected from all public universities. Nonetheless, this does not reduce the applicability of the findings of this study in any significant way but future research can either focus on other public universities or all of them. A comparative study could also be carried out between the public and private universities to find out if the characteristics exhibited by the students in the public universities mimics those exhibited by students in the private universities.

\section{REFERENCES}

Al-Adwan, A., \& Smedley, J. (2012). Implementing e-learning in the Jordanian higher education system: Factors affecting impact. International Journal of Education and Development Using Communication Technology, 8(1), 121-135.

Al-Mushasha, N. F., \& Nassuora, A. B. (2012). Factors determining e-learning service quality in Jordanian higher education environment.pdf. Journal of Applied Science, 12(14), 1474-1480.

Boso, N., Story, V. M., \& Cadogan, J. W. (2013). Entrepreneurial orientation , market orientation , network ties , and performance : Study of entrepreneurial firms in a developing economy. Journal of Business Venturing, 28, 708-727.

Chaffey, D. (2009). E-Business and E-Commerce Management: Strategy, Implementation and Practice (4th ed.). Prentice Hall.

Collier, J. E., \& Bienstock, C. C. (2006). Measuring service quality in e-retailing. Journal of Service Research, 8(3), 260-275. http://doi.org/10.1177/1094670505278867

Cox, J., \& Dale, B. G. (2001). Research and concepts service quality and e-commerce: an exploratory analysis. Managing Service Quality: An International Journal.

Cristobal, E., Flavián, C., \& Guinalíu, M. (2007). Perceived e-service quality (PeSQ): Measurement validation and effects on consumer satisfaction and website loyalty. Managing Service Quality: An International Journal, 17(3), 317-340. http://doi.org/10.1108/09604520710744326

Cronin, J.J. and Taylor, S.A. (1992), “Measuring service quality: a reexamination and extension”, Journal of Marketing, Vol. 56, 55-68

Davis, F. (1989). Perceived usefulness, perceived ease of use, and user acceptance. MIS Quarterly, 13, 319-339. http://doi.org/10.2307/249008

Fassnacht, M., \& Koese, I. (2006). Quality of electronic services: Conceptualizing and testing a hierarchical model. Journal of Service Research, 9(1), 19-37. http://doi.org/10.1177/1094670506289531

Fitzsimmons, J. A., \& Fitzsimmons, M. J. (2006). Service Management: Operations, Strategy, and 
Information Technology (5th ed.). New York NY: McGraw-Hill/Irwin.

Georgiadis, E. S. C. K. (2009). E-service quality : comparing the perceptions of providers and customers. Managing Service Quality: An International Journal, 19(4), 410-430. http://doi.org/10.1108/09604520910971539

Hair., J. F., Black, W. C., Babin, B. J., \& Anderson, R. E. (2014). Multivariate data analysis William C. Black Seventh Edition (7TH ed.). England: Pearson Education Limited.

Kausar, F. K., \& Bokhari, R. H. (2010). Exploring the factors associated with quality of website. Global Journal of Computer Science and Technology, 10(14), 37-45.

Kilburn, A., \& Kilburn, B. (2014). The mediating role of perceived value in the e-service quality-loyalty linkage among online higher education students end report. Research of Instructional Technology in Education, 1-10.

Kim-soon, N., Rahman, A., \& Ahmed, M. (2014). E-service quality in higher education and frequency of use of the service. International Education Studies, 7(3), 1-10. http://doi.org/10.5539/ies.v7n3p1

Kothari, C. R. (2004). Research methodology: Methods and techniques (2nd Ed). New Delhi: New Age International Limited Publishers.

Li, H., Liu, Y., \& Suomi, R. (2009). Measurement of e-service quality: An empirical study on online travel service. In European Conference on Information $S$ ystems.

Li, H., \& Suomi, R. (2009). A proposed scale for measuring e-service quality. International Journal of Uand E-Service, Science and Technology, 2(1), 1-10.

Loiacono, E. T., Watson, R. T., \& Goodhue, D. L. (2002). WebQual ${ }^{\mathrm{TM}}$ : A measure of website quality WebQual $^{\mathrm{TM}}$ : A measure of website quality. Marketing Theory and Applications, 13(706), 432-438.

Mohsan, F., \& Nawaz, M. M. (2011). Impact of customer satisfaction on customer loyalty and intentions to switch: Evidence from banking sector of Pakistan. International Journal of Business and Social Science, 2(16), 263-270.

Monsuwé, T. P. Y., Dellaert, B. G. C., \& Ruyter, K. D. (2004). What drives consumers to shop online? A literature review. International Journal of Service Industry Management, 15(1), 102-121. http://doi.org/10.1108/09564230410523358

Ozkan, S., \& Koseler, R. (2009). Multi-dimensional students' evaluation of e-learning systems in the higher education context: An empirical investigation. Computers \& Education, 53(4), 1285-1296. http://doi.org/10.1016/j.compedu.2009.06.011

Pallant, J. (2007). SPSS Survival Manual: A step by step guide to data analysis using SPSS for windows (Third Edit). New York NY: Open University Press (McGraw Hill Education).

Parasuraman, A., Zeithaml, V. A., \& Malhotra, A. (2005a). A multiple-item scale for assessing electronic service quality. Journal of Service Research, $7(X), 1-21$. http://doi.org/10.1177/1094670504271156.

Pulse.com.gh (2015). UG, KNUST and UDS ranked best universities in Ghana. Viewed on 30th May, 2016 at: $\quad$ http://pulse.com.gh/campus/ratings-ug-knust-and-uds-ranked-best-universities-in-ghanaid 4262026.html.

Ramayah, T., Wai, J., \& Lee, C. (2012). System characteristics, satisfaction and e-learning usage: A Structural Equation Model ( SEM ) 1. The Turkish Online Journal of Educational Technology, 11(2), 2628.

Rareș, O. D. (2014). Measuring perceived service quality offline vs . online : a new PeSQ conceptual model. Procedia Economics and Finance, 15(14), 538-551. http://doi.org/10.1016/S2212-5671(14)00505$\mathrm{X}$.

Reinders, M. J., Hagen, M. Van, \& Frambach, R. T. (2007). Customer evaluations of self-service technologies in public transport. Association for European Transport and contributors.

Sanayei, A., \& Jokar, A. (2013). Determining the effect of electronic services quality on electronic satisfaction and positive word of mouth ( case study): Different branches of shiraz mellat bank customers. International Journal of Academic Research in Accounting, Finance and Management Sciences, 3(4), 103-111. http://doi.org/10.6007/IJARAFMS/v3-i4/360.

Santos, J. (2003). E-service quality: a model of virtual service quality dimensions. Managing Service Quality: An International Journal, 13(3), 233-246. http://doi.org/10.1108/09604520310476490.

Saunders, M., Lewis, P., \& Thornhill, A. (2007). Research Methods for Business Students (4th Editio). Edinburgh Gate: Pearson Education Limited.

Shapor, A., Jahromi, S., Ahmadi, E., Fakhravari, F., \& Adiby, P. M. (2011). The examination electronic 
services quality of sina bank with E-SERVQUAL model in Shiraz Branches. International Conference on Advancements in Electronics and Power Engineering (pp. 78-82). Bangkok.

Sohn, C., \& Tadisina, S. K. (2008). Development of e-service quality measure for internet-based financial institutions. Total Quality Management \& Business Excellence, 19 (February), 903-918. http://doi.org/10.1080/14783360802224412

Sutarso, Y., \& Auharmdi, A. (2011). Promotion of E-Technology-Based Services: A Case Study of EService Quality at a University in Indonesia. International Journal of Business and Information, 6(1), $112-133$.

Swaid, S. I. (2008). Developing an instrument for measuring electronic shopping service quality: ESQUAL. In Southern Association for Information Systems Conference (pp. 1-5).

Swaid, S. I., \& Wigand, R. T. (2009). Measuring the quality of e-service: scale development and initial validation. Journal of Electronic Commerce Research, 10(1), 13-28.

Vankatesh, V., Morris, M. G., Davis, G. B., \& Davis, F. D. (2003). User acceptance of information technology: Toward a unified view. MIS Quarterly, 27(3), 425-478. http://doi.org/10.2307/30036540

Wang, M. (2003). Assessment of E-Service Quality via E-Satisfaction in E-Commerce Globalization. Electronic Journal of Information Systems in Developing Countries. 11(10) 1-4.

Wolfinbarger, M., \& Gilly, M. C. (2003). eTailQ: Dimensionalizing, measuring and predicting retail quality. Journal of Retailing, 79, 183-198. http://doi.org/10.1016/S0022-4359(03)00034-4.

Yi, M. Y., \& Hwang, Y. (2003). Predicting the use of web-based information systems: Self-efficacy, enjoyment, learning goal orientation, and the technology acceptance model. International Journal of Human Computer Studies, 59, 431-449. http://doi.org/10.1016/S1071-5819(03)00114-9.

Yoo, B., \& Donthu, N. (2001). Developing a scale to measure the perceived quality of an Internet shopping site (SITEQUAL). Quarterly Journal of Electronic Commerce, 2(1), 31-47. Retrieved from http://people.hofstra.edu/Boonghee_Yoo/papers/2001_QJEC_SITEQUAL.pdf

Zeithaml, V. A., Parasuraman, A., \& Malhotra, A. (2002). Service quality delivery through websites : A critical review of extant knowledge. Journal of the Academy of Marketing Science, 30(4), 362-375. http://doi.org/10.1177/009207002236911 